\title{
Guidelines for Branch Libraries in Colleges and Universities
}

Approved as policy by the Board of Directors of the Association of College and Research Libraries, on July 3, 1975.

\section{INTRODUCTION}

One of the most persistent and difficult organizational issues for academic libraries is the physical centralization or decentralization of library services. When should a branch library be created? Are established ones effective? The following Guidelines were developed by the Association of College and Research Libraries in response to requests from academic librarians and administrators for criteria to assist them in reviewing the need for branch libraries at their institutions. Their objective is to provide a framework for assessing the need for branch libraries and for developing policies for administering effective branch services.

In this document, the term "branch" has been used generally to define a library service unit, with collections, which is usually physically removed from the main library. It encompasses a variety of references, including:

Department and professional libraries with collections and services organized primarily to serve the needs of one or two academic disciplines.

Divisional libraries with collections and services organized to serve the needs of several related subject fields, including interdisciplinary studies.

Undergraduate libraries with collections and services organized to meet particular instruction needs of the institution.

\section{The Guidelines}

Branch libraries under a variety of designations have been established to extend the services of the main library at many academic institutions. Factors governing their development include the mission of the institution, campus geography, enrollment patterns, financial conditions, space requirements, instructional techniques, user expectations and demands, and external pressures. These guidelines identify the primary factors influencing the development and maintenance of branch library collections and services. A review of these factors as they relate to local circumstances should assist librarians and their institutions in evaluating the need for branch libraries and enable them to make sound decisions related to establishing or continuing branch libraries. The reviewing process is described in the following two sections:
Need Analysis and Evaluation, and Operating Policies.

\section{Need ANalysis and Evaluation}

The needs of modern scholarship must be served by access to a broad spectrum of resources, including the literature of a special field and all subjects of related interest. The basic objectives of the academic library are to acquire, organize, store and disseminate recorded information, and to provide services by which to obtain it locally, or to guide and assist the user to appropriate external sources. The library user's major concern is for the totality of the resources available to him. All recorded resources commonly used to enrich or support the learning process, and which are owned by or on loan to the academic institution, are information resources. These resources should be included as part of the inventory administered by the library so that standards of collection development and service can be maintained at reasonable cost.

An analysis of need for branch libraries should account for the requirements of a branch library's primary clientele as well as those of the entire academic community. The analysis should include supporting data covering the following points:

I. The educational philosophy and objectives of the institution, and the role of library services within this context.

2. A description of projected branch services including-

a. Its primary clientele (students, faculty, academic departments) and their information needs.

b. Geographical location related to primary clientele and to the total community of users.

c. Collection development and organization plans, including projections of maximum size.

d. User services, including hours of access and on-site staffing requirements.

e. Access to union catalogs, delivery services, and specialized information systems.

f. Space and equipment requirements, including growth projections to meet changing needs.

g. Total development and operating costs, including long-range projections to meet growth needs.

3. A description of present library services, including- 
a. Information needs of the total community defining both general and special requirements.

b. Geographical location of present facilities related to users' locations.

c. Collection development policies and physical organization of the collection, including cross-disciplinary needs of the academic community and collection growth projections.

d. User services, including hours of access and on-site staffing requirements.

e. Union catalogs, delivery systems and specialized information systems.

f. Space and equipment requirements, including growth projections to meet changing needs.

g. Financial support requirements, including long-range projections to meet growth needs.

4. A comparative analysis of projected branch services and existing library services, using each of the factors identified in points 1,2 and 3. Note should be made of the following:

a. Restrictions on user access to collections and services, such as geography, transportation facilities, collection arrangements, delivery services for library materials, service hours, staffing assistance, and special use privileges for defined group of clientele.

b. Collection development and arrangement requirements, including the cost of duplicating library resources, and developing new subject collections.

c. Space and equipment requirements, including the cost of establishing and maintaining new facilities.

d. Financial support requirements, including long-range projections to meet growth needs. This should include a review of the institution's long-range projections for financial support of its library programs.

Implicit with the creation of a branch is a commitment to funding its development, on-going services, and growth while maintaining adequate support levels for library services required by the total academic community.

\section{Administrative Phinciples}

The decision to establish or continue a branch library should be accompanied by administrative policy statements clearly defining the responsibilities of the library system, including its branches. Library policy statements supporting objectives and operating procedures of branches should cover the following: the purpose of the branch; administrative structure; collections development; services; staffing; and facilities. To fit into the larger framework of the institution's objectives and programs, these policy statements should be approved by the library director and appropriate administrative officers, and supported by committees representing a variety of interest groups.

The following general principles should be considered in drafting policies for managing branch libraries:

\section{Organization}

The responsibility for the management of all libraries, both main and branch, should rest with the library administration. Library services are most effective when all the institution's library resources are considered part of one system with consistent policies for access, accounting, analysis and the like. Centralized planning and direction are necessary to achieve the best use of the financial resources an institution can allocate for library services.

The branch library staff should report to the main library administration. This relationship should be defined in job descriptions and outlined on organization charts.

Written statements defining goals and objectives of a branch library should be determined carefully, described clearly, updated regularly, and stated in measurable terms. The review and evaluation of branch operations should be conducted with the assistance of the library's advisory committees representing the interests of the total academic community.

A manual of operating policies and procedures is recommended for all branch libraries.

\section{Collections Development}

The materials selection policy for each branch should be coordinated with the main library's selection policies. The policy should emphasize the branch's goals and objectives as the foundation for acquisitions, and the framework within which the branch collection is to be evaluated. The collection should be restricted, as far as possible, to the subjects the branch serves, and should include all forms of material necessary to support those fields. An explicit policy covering the provision of duplicate materials, whether in the main library, or in a branch, is essential. Discarding policies should be included in selection policy statements.

\section{Collection Organization}

Whenever centralization can produce significant economies in processing and acquisitions, it should be effected. However, 
an analysis should be made in each case since no absolute rule or guideline can be established. In most cases, centralized processing and acquisitions will prove most economical.

The holdings of a library system, including those of branch libraries, should be listed in union catalogs and other access points to the collections, and be open to the library's general community. Branch users should have access to the files of the branch's holdings, union lists and other similar records produced by the library system in the branch.

\section{Services}

Branch libraries should maintain the same standards of service, but not necessarily the same services, as the main library with respect to access, staffing, assistance to users and adequacy of physical facilities. To this end-
Branch services, including circulation privileges, should be available to the total academic community at hours convenient to the users. Delivery and photocopy services are encouraged to provide maximum accessibility to and utilization of the materials.

Competent staffing should be provided to insure the proper development and use of the library's collection. The staff is a primary link between the community's needs and the library's collections.

The quality of branch services depends on its responsiveness to its user's needs. It is essential that the intended users of the branch be consulted periodically to advise the branch on developing and evaluating its services.

Reprints of this article are available, upon request, from the ACRL Office, $50 \mathrm{E}$. Huron $\mathrm{St}$., Chicago, IL 60611 .

\section{Committee Appointed to Write Quantitative Standards for "Guidelines for Two-Year}

\section{College Learning Resources Programs"}

The Association of College and Research Libraries announces the appointment of a committee to develop quantitative standards to supplement the "Guidelines for Two-Year College Learning Resources Programs."

William J. Hoffman, dean of educational resources and library services at Mt. San Antonio College, Walnut, California, will chair the committee. Other members of the committee are: Imogene I. Book, director of the library at Rend Lake College, Ina, Illinois; Glenn R. Dallman, director of library services at St. Petersburg Junior College, Clearwater, Florida; Harriett Genung, Upland, California; Leah K. Nekritz, director of learning resources at Prince George's Community College, Largo, Maryland; Robert F. Schremser, head librarian at Alexander City State Junior College, Alexander City, Alabama; and Fleming $\mathrm{A}$. Thomas, chairman of the Division of Learning Resources at Burlington County College, Pemberton, New Jersey. Dr. Sarah $\mathrm{K}$. Thomson, chairman of the Library and Learning Resources Department at Bergen Community College, Paramus, New Jersey, will serve as consultant to the committee.

The "Guidelines for Two-Year College Learning Resources Programs" were approved as ACRL policy in June 1972. They supersede and replace the "Standards for Junior College
Libraries" adopted by the association in May 1960. The "Guidelines" were prepared by a joint committee of members from the American Association of Community and Junior Colleges, the Association for Educational Communications and Technology, and the Association of College and Research Libraries.

The "Guidelines for Two-Year College Learning Resources Programs" are diagnostic and descriptive in nature. They offer an institution criteria for self-study and planning. The quantitative supplement now being prepared will provide a means for assessing the adequacy of the learning resources program. When the supplement is completed, the standards for two-year programs will contain both qualitative and quantitative elements.

The committee will meet during the American Library Association's Midwinter Meeting, January 18-24, 1975, in Chicago. Prior to the meeting, it will examine all of the existing quantitative statements relating to two-year colleges and learning resources centers. The committee requests that education agencies and state, regional, and national professional associations which have prepared quantitative standards send a single copy of their standards to the Association of College and Research Libraries, 50 E. Huron St., Chicago, IL 6061l. 